\title{
In vitro rumen fermentation of tropical browse seeds in relation to their content of secondary metabolites*
}

\author{
O.J. Babayemi ${ }^{1}$, D. Demeyer ${ }^{2}$ and V. Fievez ${ }^{2,3}$ \\ ${ }^{1}$ Department of Animal Science, University of Ibadan, Nigeria \\ ${ }^{2}$ Department of Animal Production, University of Ghent, Belgium
}

\begin{abstract}
Seeds of four tropical multipurpose trees (Albizia saman, Albizia lebbeck, Albizia rhizonse, Leucaena leucocephala), two shrubs (Tephrosia candida, Tephrosia bracteolata) and two pulse legumes (Lablab purpureus, Canavalia ensiformis) were supplemented (125 mg) to straw (375 mg) in batch in vitro incubations using rumen content as inoculum. All seeds have been suggested to be useful protein supplements. Moreover, Albizia lebbeck and Albizia rhizonse, containing saponins, showed the ability to reduce rumen methane production, probably due to reduced protozoal numbers as suggested by lower butyrate productions. There was a suggestion of reduced protein degradability in the shrub seeds, containing condensed tannins.
\end{abstract}

KEY WORDS: seeds, saponins, tannins, rumen, fermentation, methanogenesis

\section{INTRODUCTION}

The majority of tropical livestock has access only to low quality pastures and crop residues or by-products of relatively low nutritive value. Nevertheless, there is a variety of plants, seeds and fruits which remain still relatively unexplored as feed supplement for ruminant production. Many seeds, being high in protein could be suitable as concentrate feed for ruminants, but often contain secondary plant metabolites, which may provoke beneficial as well as anti-nutritional effects to ruminants. This study aimed at evaluating rumen fermentation characteristics of seeds from Albizia saman, A. rhizonse, A. lebbeck, Leucaena leucocephala, Tephrosia candida, T. bracteolata, Lablab purpureus and Canavalia ensiformis in

\footnotetext{
" O.J. Babayemi is grateful to the John D. and Catherine T. MacArthur Foundation Grant through the University of Ibadan, Nigeria as support for Staff Development and Training and to Andy Deprez for technical assistance

${ }^{3}$ Corresponding author: e-mail: Veerle.Fievez@ugent.be
} 
relation to their content of secondary plant metabolites, as qualitatively determined using analytical methods, requiring a minimum of laboratory equipment and facilities.

\section{MATERIAL AND METHODS}

Rumen fluid was obtained from two fistulated sheep before the morning feed and used for incubation $(25 \mathrm{ml})$ after mixing with phosphate buffer $(1 / 4, \mathrm{v} / \mathrm{v})$ (Fievez et al., 2003). In contrast to the latter study, the buffer was void of $\mathrm{NH}_{4} \mathrm{Cl}$ and 375 $\mathrm{mg}$ of straw with $125 \mathrm{mg}$ of one of the eight seeds was added. Animals were fed twice daily a hay/grain based concentrate $(65 / 35, \mathrm{w} / \mathrm{w} \mathrm{DM})$ diet at maintenance, but only hay was fed during the last $24 \mathrm{~h}$ before the collection of rumen liquor in order to exhaust rumen $\mathrm{NH}_{3}$ concentrations in the inoculum. After $24 \mathrm{~h}$ of incubation, 1 $\mathrm{ml}$ of the gas phase was taken with a gastight syringe and analysed for $\mathrm{CH}_{4}$ by gas chromatography. This procedure as well as $\mathrm{pH}$ measurements, and preparation and analysis of VFA by gas-liquid chromatography were as described earlier (Fievez et al., 2003). Data were subjected to analysis of variance and Duncan F-test.

The seeds were analysed for dry matter (DM), crude protein $(\mathrm{CP})$, ether extract, ash and neutral detergent fibre (NDF) according to conventional methods. Saponins and phenols were determined as described earlier (Larrahondo, 1985), with some modifications: $2 \mathrm{~g}$ of seeds were extracted in duplicate with petroleum ether $(30 \mathrm{ml})$ and methanol-water (MW, 9/1, v/v, $25 \mathrm{ml})$. The mixture was agitated for $90 \mathrm{~min}$, filtered and separated by a funnel. The lower (MW) and upper (petroleum ether) layer were collected into $50 \mathrm{ml}$ volumetric flasks. From the MW fraction, $1.67 \mathrm{ml}$ was dispensed in $9 \mathrm{ml}$ distilled $\mathrm{H}_{2} \mathrm{O}$, filtered and $1 \mathrm{ml}$ pipetted in a tube. Since saponins form soapy lather when agitated in water, the tube was shaken for $30 \mathrm{~s}$ and left to stand for $15 \mathrm{~min}$. Saponin content was evaluated from the height of the foam layer as negative $(<5 \mathrm{~mm})$, low $(5-9 \mathrm{~mm})$, medium $(10-14$ $\mathrm{mm})$ and high $(>15 \mathrm{~mm})$. For phenol determination, $1 \mathrm{ml}$ from the MW fraction was pipetted into five bottles with $1 \% \mathrm{FeCl}_{3}(\mathrm{w} / \mathrm{v})$ added at different levels $(0.2$, 0.4, 0.6, 0.8 and $1 \mathrm{ml}$, respectively). Phenols form complexes with ferric ion, resulting in a blue-violet solution and hence, their presence was scored as: no phenols (no colour change), hydrolysable (dark blue) and condensed tannins (dark green).

\section{RESULTS}

Table 1 shows the results for proximate analysis as well as the qualitative evaluation of the presence of saponins and phenols in the seeds investigated. It is clear that saponins were detected in Albizia seeds only, whereas hydrolysable and condensed tannins were detected in Leucaena and Tephrosia seeds, respectively. 
Table 1. Crude protein (CP) and neutral detergent fibre (NDF) content (g/100 g DM) and qualitative evaluation of the presence of saponins and phenols in tropical browse seeds

\begin{tabular}{|c|c|c|c|c|c|c|}
\hline \multirow[b]{2}{*}{ Seed species } & \multicolumn{2}{|c|}{ Composition } & \multicolumn{2}{|c|}{ Saponins } & \multicolumn{2}{|c|}{ Phenols } \\
\hline & $\mathrm{CP}$ & NDF & $\begin{array}{c}\text { foam } \\
\mathrm{mm}\end{array}$ & comment & $\begin{array}{l}\text { colour } \\
\text { change }\end{array}$ & comment \\
\hline \multicolumn{7}{|l|}{ Multipurpose trees } \\
\hline Albizia saman & 29.3 & 26.0 & 1 & negative & no & negative \\
\hline Albizia lebbeck & 32.5 & 24.0 & 8 & low & no & negative \\
\hline Albizia rhizonse & 33.4 & 27.4 & 6.5 & low & no & negative \\
\hline Leucaena leucocephala & 27.6 & 43.3 & 1 & negative & dark blue & hyd. $\tan .^{2}$ \\
\hline \multicolumn{7}{|l|}{ Shrubs } \\
\hline Tephrosia candida & 38.2 & 27.0 & 0 & negative & dark green & con. $\tan ^{2}$ \\
\hline Tephrosia bracteolata & 38.1 & 22.1 & 0 & negative & dark green & con. $\tan ^{2}$ \\
\hline \multicolumn{7}{|l|}{ Pulses } \\
\hline Lablab purpureus & 24.8 & 46.9 & 0 & negative & no & negative \\
\hline Canavalia ensiformis & 25.3 & $-{ }^{1}$ & 2 & negative & no & negative \\
\hline
\end{tabular}

${ }^{1}$ not detectable due to clogging of the seed in the Fibertec apparatus

${ }^{2}$ hyd. tan. - hydrolysable tannins; con. tan. - condensed tannins

Table 2 presents in vitro fermentation characteristics, in terms of total VFA production and relative production of individual VFA and $\mathrm{CH}_{4}$.

Table 2. Total ( $\mu \mathrm{mol} /$ incubation) VFA production and relative ( $\mathrm{mmol} / \mathrm{mol}$ total VFA) production of individual VFA and $\mathrm{CH}_{4}$ during $24 \mathrm{~h}$ in vitro incubation of straw and browse seeds $(\mathrm{n}=3)$

\begin{tabular}{|c|c|c|c|c|c|c|}
\hline Seed species & Total VFA & Acet $^{1}$ & Prop $^{1}$ & But $^{1}$ & Ival $^{1}$ & $\mathrm{CH}_{4}$ \\
\hline \multicolumn{7}{|l|}{ Multipurpose trees } \\
\hline Albizia saman & $1491^{\mathrm{ab}}$ & $710^{\mathrm{a}}$ & $169^{c}$ & $99^{\mathrm{ab}}$ & $19^{\mathrm{b}}$ & $332^{\mathrm{a}}$ \\
\hline Albizia lebbeck & $1197^{\mathrm{bc}}$ & $676^{\mathrm{ab}}$ & $230^{\mathrm{ab}}$ & $66^{\mathrm{de}}$ & $23^{\mathrm{b}}$ & $293^{\mathrm{ab}}$ \\
\hline Albizia rhizonse & $1161^{c}$ & $656^{\mathrm{b}}$ & $246^{\mathrm{a}}$ & $54^{\mathrm{e}}$ & $38^{\mathrm{a}}$ & $274^{\mathrm{b}}$ \\
\hline Leucaena leucocephala & $1351^{\mathrm{abc}}$ & $688^{\mathrm{ab}}$ & $212^{\mathrm{abc}}$ & $86^{\mathrm{bc}}$ & $15^{\mathrm{b}}$ & $325^{\mathrm{ab}}$ \\
\hline \multicolumn{7}{|l|}{ Shrubs } \\
\hline Tephrosia candida & $1460^{\mathrm{ab}}$ & $683^{\mathrm{ab}}$ & $176^{\mathrm{c}}$ & $101^{\mathrm{ab}}$ & $25^{\mathrm{ab}}$ & $347^{\mathrm{a}}$ \\
\hline Tephrosia bracteolata & $1587^{\mathrm{a}}$ & $670^{\mathrm{b}}$ & $190^{b c}$ & $100^{\mathrm{ab}}$ & $26^{\mathrm{ab}}$ & $323^{\mathrm{ab}}$ \\
\hline \multicolumn{7}{|l|}{ Pulses } \\
\hline Lablab purpureus & $1596^{\mathrm{a}}$ & $680^{\mathrm{ab}}$ & $186^{\mathrm{c}}$ & $106^{\mathrm{a}}$ & $22^{\mathrm{b}}$ & $334^{a}$ \\
\hline Canavalia ensiformis & $1568^{\mathrm{a}}$ & $669^{\mathrm{b}}$ & $232^{\mathrm{a}}$ & $77^{\mathrm{cd}}$ & $19^{b}$ & $317^{\mathrm{ab}}$ \\
\hline SEM & 53.3 & 6.6 & 7.4 & 3.4 & 2.4 & 9.5 \\
\hline
\end{tabular}


Supplementation of A. lebbeck and particularly A. rhizonse to incubations with straw tended to reduce relative $\mathrm{CH}_{4}$, acetate and butyrate production and showed relatively higher propionate productions. Total VFA production was lower and represented about $75 \%$ of the total VFA production observed when incubating straw supplemented with seeds of pulses which induced the highest VFA productions.

\section{DISCUSSION}

Seeds of $A$. lebbeck and A. rhizonse seem to have the potential to slightly depress rumen methanogenesis. Relative butyrate productions were significantly lower in these incubations, suggesting that $\mathrm{CH}_{4}$ depression was indirect through the suppression of protozoa, the main butyrate producers in the rumen. These effects might be related to the presence of saponins in these seeds, potentially acting as a defaunating agent (Teferedegne, 2000). However, it should be noted that these relatively beneficial shifts in the fermentation pattern were associated with lower total rumen degradability, as evident from the reduced values for total VFA production. Variation in isovalerate proportions were reflecting differences in CP content of the seeds, except for the two shrub seeds, which showed lower isovalerate proportions than expected. This might be due to the presence of condensed tannins in these seeds, which have been reported to diminish rumen protein digestibility (e.g., Barry and McNabb, 1999).

\section{CONCLUSIONS}

Proximate analysis indicates that the selected seeds might be useful protein supplements in ruminant feeding. Moreover, saponin containing seeds showed the ability to reduce rumen methane and butyrate production, whereas lowered protein degradability was suggested for seeds containing condensed tannins.

\section{REFERENCES}

Barry T.N., McNabb W.C., 1999. The implications of condensed tannins on the nutritive value of temperate forages fed to ruminants. Brit. J. Nutr. 81, 263-272

Fievez V., Dohme F., Danneels M., Raes K., Demeyer D., 2003. Fish oils as potent methane inhibitors and associated effects on rumen fermentation in vitro and in vivo. Anim. Feed Sci. Tech. 104, 41-58

Larrahondo J.E., 1985. Productos naturals: pruebas quimicas en una planta. Quia de estudio del Departamento de Quimica, Universidad del Valle, pp. 10

Teferedegne B., 2000. New perspectives on the use of tropical plants to improve ruminant nutrition. Proc. Nutr. Soc. 59, 209-214 